\title{
Study on Bilingual Teaching Reform of Applied Business Talent SPI Ability Chain
}

\author{
Zhixia Zhou* \\ Economy and Management Department \\ Weifang University \\ Weifang, China \\ wfxyzhouzhixia@126.com
}

\author{
Peng Liu \\ Economy and Management Department \\ Weifang University \\ Weifang, China \\ Wflp888@163.com
}

\begin{abstract}
This thes is aimed to improve the ability of appliedtype business talents through the implementation of bilingual teaching under the background of education internationalization. By using field research and comparative analysis methods, it discovered that SPI ability chain bilingual educating system with the core of "study-practice-innovation" is effective to promote bilingual teaching effects. Based on long-term bilingual teaching theory research and teaching practice of front-line teachers, it put forward bilingual teaching reform suggestions.
\end{abstract}

Keywords-Applied-type business talents; Bilingual teaching; Study-practice-innovation education; SPI ability chain

\section{INTRODUCTION}

Under the background of economic globalization, the implementation of effective bilingual education is a key way to train international talents. However, the current supply of talents under the bilingual education mode can not meet the exuberant needs of international talents for the current society, which makes bilingual education validity has been widely questioned, these questions were mainly focused on[1]: Bilingual teaching in colleges and universities can overcome the limitations of the lack of foreign language environment in China or not? Bilingual teaching in universities can maintain a balanced development of bilingual or not? Can Bilingual Teaching in Colleges and universities achieve an orderly link with college English teaching and professional English teaching or not? In recent years, the ascendant internationalization of education has provided new opportunities and ideas for people to re-examine the bilingual education in colleges and universities. First of all, the internationalization of education and the objective trend of the future development of the country and students have promoted the reform of college English teaching methods, which makes the necessity of bilingual teaching more persuasive. Second, the promotion of internationalization of education has accelerated the innovation of educational business processes, and the reform of teaching language in academic education has become urgent. Therefore, the implementation of bilingual teaching reform is a very urgent strategic choice for the internationalization of China's higher education[2] (Dai yuncai, 2012), and is an important measure for the reform of higher education curriculum in China ${ }^{[3]}$ (Cai jigang, 2012).
II. THE APPLICATION OF BILINGUAL BUSINESS SKILLS AS THE CORE OF BILINGUAL BUSINESS EDUCATION MODEL

\section{A. Bilingual business education model construction}

Aiming at the problems of imperfect course system such as: poor professional teaching, inactive interaction between teachers and students, lack of communication environment in foreign languages, imperfect practice teaching platform, inadequate training of students' ideological nature, weakness of applied innovative ability and so on, the thesis identified an application-based business manpower training model centered on "Study-practice-innovation" SPI bilingual competence chain. The practice proved that this model was an effective solution to practical teaching problems (see Fig. 1).

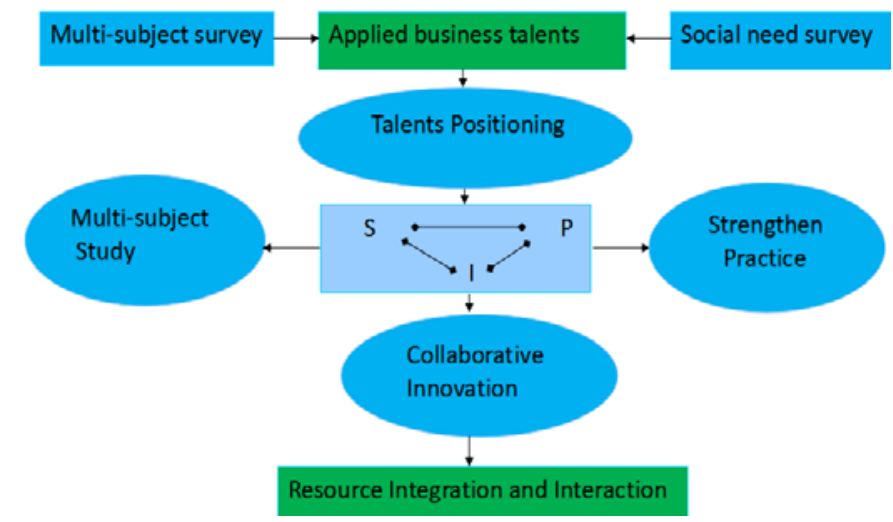

Fig. 1. SPI Bilingual Competence Chain Educating Mode

\section{B. Bilingual business education model implementing steps}

Specific implementation steps are as follows:

(1) Clear application of high-quality personnel training positioning (SPI ability chain). Through a wide range of associations among organizations such as: social research, interviewed enterprises, government, alumni, universities and other related groups, a clear positioning of personnel training;

(2) Diversified teaching mode (bilingual learning ability). Through the second classroom, the teachers expanded students' professional knowledge, through the sunny classroom, improved students' bilingual learning ability;

(3) Strengthen the theoretical teaching and practical teaching system (bilingual practical ability). Changed the 
traditional education model with teachers as the main body, aroused the enthusiasm of students and improved the ability of study and practice;

(4) Expand the multi-coordinated interactive mode of education (application of innovative capabilities). Through contacts with relevant enterprises, universities, industries and other subjects, we integrated social resources, and greatly improved students’ ability to apply innovation.

III. THE APPLICATION OF BILINGUAL BUSINESS SKILLS AS THE CORE OF THE BILINGUAL BUSINESS EDUCATION MODEL TO PROMOTE THE IMPLEMENTATION OF

\section{A. SPI bilingual ability to build and implement the chain}

This achievement has replaced the traditional ideas of classroom teaching center by introducing the concept of competency, which was based in the process of cultivating applied talents, analyzing and constructing the SPI bilingual competence chain of "study-practice-innovation" of business talents. Focusing on the cultivation of students' professional abilities, the basic qualities and abilities of business professionals should be divided into two parts of Study Practice, in which the special ability of discipline innovation and special training were in all aspects of teaching[4]. A variety of capabilities of organic links, constituted the SPI bilingual competence chain (see Fig. 2), through the all-round multi-agent collaborative interaction, innovative personnel training mode was built. The model of SPI bilingual competence for business professionals has had a high theoretical innovation value[5], this model has been highly praised by relevant institutions, society and enterprises for its bilingual teaching practice.

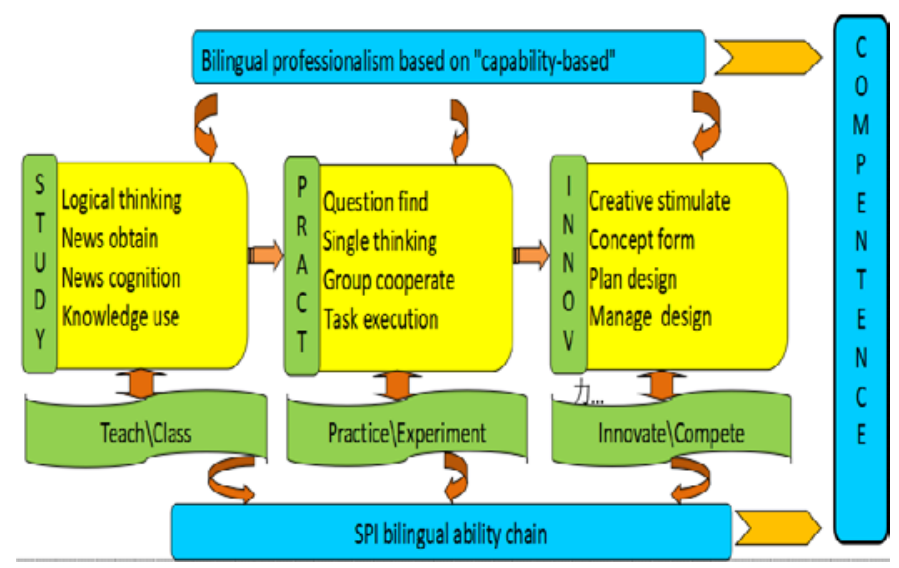

Fig. 2. SPI Bilingual Ability Chain Components

\section{B. Application-oriented commercial chain of bilingual} learning system construction and application of promotion

Based on bilingual courses of "International business negotiation" and "International settlement" were approved as a bilingual teaching demonstration project in Shandong Province, as well as courses of "International marketing" and "International commercial law" were approved as the construction of bilingual courses at the university level, we focused on the training objective and characteristics of the application-oriented professionals. Considering its own resources and subject trends, based on the bilingual teaching concept of "seeking truth from facts, teaching students in accordance with their aptitudes", we built and implemented a chain-type bilingual learning system ${ }^{[6]}$ (see TABLE I).

The chain bilingual curriculum system and the "Ladder-in" bilingual teaching system have been implemented in the international economy and trade and marketing major of Economics and management faculty since 2012, since 2013, they have been applied and promoted at Beihai international college and have been well received by students. This teaching system has effectively solved many problems existing in applied undergraduates for a long time, which include ambiguous positioning, unclear ideas and ineffective teaching.

TABLE I. CHAIN BILINGUAL LEARNING SYSTEM FOR APPLIED BUSINESS TALENT

\begin{tabular}{|l|l|l|}
\hline Design & Execution Contents & Execution Effect \\
\hline $\begin{array}{l}\text { Chained } \\
\text { curriculum } \\
\text { system }\end{array}$ & $\begin{array}{l}\text { Improve teaching materials } \\
\text { Increase English knowledge } \\
\text { Expand English application } \\
\text { Optimize professionalcourse }\end{array}$ & $\begin{array}{l}\text { Rich knowledge chain \& } \\
\text { Strong professional } \\
\text { extension }\end{array}$ \\
\hline $\begin{array}{l}\text { Ladder } \\
\text { teaching } \\
\text { system }\end{array}$ & $\begin{array}{l}\text { Grading teaching contents } \\
\text { Develop teaching resources } \\
\text { Design teaching methods }\end{array}$ & $\begin{array}{l}\text { From transitionalto } \\
\text { infiltration teaching } \\
\text { transition }\end{array}$ \\
\hline
\end{tabular}

\section{Applied Business Talents flip bilingual teaching model} construction and application of promotion

Based on the teaching reform project of Shandong Province and Weifang University, our achievements have been continuously carried out in teaching practice. The teaching model of flip-flop bilingual teaching has been constructed and implemented under the guidance of overturning classroom and participatory interactive teaching (see TABLE II). Since 2015, Mixed-Flip-Bilingual teaching modes and strategies have been applied and implemented in International business negotiations, International marketing and International business law courses, we have made up different foreign language proficiency through personalized learning differences according to each of individual student, which has been welcomed by students, and has been implemented in other economic management professionals.

TABLE II. FLIPPING BILINGUAL TEACHING MODE FOR APPLIED BUSINESS TALENTS

\begin{tabular}{|l|l|l|}
\hline Design & Execution Contents & Execution Effect \\
\hline $\begin{array}{l}\text { Flipping } \\
\text { classroom } \\
\text { system }\end{array}$ & $\begin{array}{l}\text { Expand bilingual content Recognize } \\
\text { bilingual resources Optimize flipping } \\
\text { environment }\end{array}$ & $\begin{array}{l}\text { Self-learning ability } \\
\text { and cooperative } \\
\text { learning awareness }\end{array}$ \\
\hline $\begin{array}{l}\text { Mixed flip } \\
\text { classroom } \\
\text { mode }\end{array}$ & $\begin{array}{l}\text { Deepen self-learning mode Expand } \\
\text { internal knowledge Improve post- } \\
\text { class knowledge Adopt flipping case } \\
\text { teaching }\end{array}$ & $\begin{array}{l}\text { New teaching model } \\
\text { based on information } \\
\text { technology }\end{array}$ \\
\hline $\begin{array}{l}\text { Mixed flip } \\
\text { teaching } \\
\text { strategy }\end{array}$ & $\begin{array}{l}\text { Evaluation of teaching strategies In- } \\
\text { school flip teaching strategies Role } \\
\text { flipping teaching strategies }\end{array}$ & $\begin{array}{l}\text { Increase teacher- } \\
\text { student interaction }\end{array}$ \\
\hline
\end{tabular}




\section{Applied bilingual commercial contextualized practical platform construction and application of promotion}

As the results of a variety of integrated teaching resources, we set up the whole process of multi-angle contextualized bilingual practice platform(see TABLE III).

TABLE III. SITUATIONAL BILINGUAL PRACTICE PLATFORM FOR APPLIED BUSINESS TALENTS

\begin{tabular}{|l|l|l|}
\hline Design & Execution Contents & Execution Effect \\
\hline $\begin{array}{l}\text { Situational } \\
\text { teaching } \\
\text { platform }\end{array}$ & $\begin{array}{l}\text { Set bilingual teaching practice } \\
\text { Build simulation platform }\end{array}$ & $\begin{array}{l}\text { Good bilingual } \\
\text { teaching simulation } \\
\text { practice }\end{array}$ \\
\hline $\begin{array}{l}\text { Situational } \\
\text { practicing } \\
\text { platform }\end{array}$ & $\begin{array}{l}\text { Construct knowledge platform } \\
\text { Share high-quality resources Rely }\end{array}$ & $\begin{array}{l}\text { Extended bilingual } \\
\text { teaching beyond the } \\
\text { classroom }\end{array}$ \\
\hline
\end{tabular}

Based on this situation-type bilingual teaching and practicing platform, the teachers guided the students actively to carry out the second class of learning, strengthened ties with export-oriented enterprises, institutions and cooperation, took the initiative to participate in various business English communication activities, and effectively improved the practical ability and level of English students. In particular, most students majoring in International Economics and Trade have strong professional English practical ability, and has been widely recognized in internship and employment units.

\section{E. Applied Business Talents collaborative innovation and education mechanism to build and promote the application}

Relying on provincial enterprise training and universityenterprise cooperation[7], we constructed the collaborative innovation and education mechanism covering collaborative education mode and innovative competition mechanism. Upon this system, we have settled key issues of staff education, and developed innovation abilities of students when they graduate. The achievements have broken through the limitations of pure cooperation between schools and enterprises; have developed synergistic interactions among school-enterprises (industries), schools (regions), schools and schools, which have carried out this synergistic interaction throughout the entire process of personnel training to popularization.

\section{CONCLUSION}

Based on the concept of "ability-base orientation", this paper constructed and popularized the application-oriented business model of talented personnel training based on SPI bilingual competence. To carry out this system, we should firstly design and popularize bilingual chain courses and "ladder-in" teaching system with rich knowledge and extensive maneuverability, secondly we should construct and popularize the bilingual teaching system, optimize mode and strategy of flip-flipped classroom under the instruction of flip classroom and participatory interactive teaching concept, thirdly we should integrate a variety of teaching resources, carry out the whole process of multi-angle contextualized bilingual practice simulation platform and knowledge platform, besides this, we also should continue to carry out the practical application of teaching achievements, collaboratively promote education mode and innovative competition mechanism.

In all, application of bilingual education system based on SPI bilingual ability chain of applied talents have significantly promoted the teaching effects of bilingual courses and promoted the internationalization of applied, innovative, bilingual and speculative international talents.

\section{ACKNOWLEDGMENT}

This thesis is founded by Shandong Province Human \& Social Science Program (17-ND-JJ-15), Ministry of Education Collaborative Education Project (201702068055), Ministry of Education Industry-University Cooperation Collaborative Education Project (201602028046), hereby express acknowledgments to them.

\section{REFERENCES}

[1] Ttan duojiao, "Bilingual teaching: strategic choice of the internationalization of China's higher education,” Education Research, vol. 11, pp. 45-47, November 2012.

[2] Dai yuncai, Wang tongshun, "Research on second language acquisition model of dynamic system theory -- interaction of environment, learner and language,” Shandong Foreign Language Teaching, vol. 5, pp. 24-26, May 2012.

[3] Cai jigang, "Research on the Positioning of College English Teaching under the Background of Education Internationalization," Foreign Languages, vol. 1, pp. 12-15, March 2012.

[4] Yan Jianhua, "Construction of innovation-based entrepreneurship education,” Chinese Higher Education, vol. 12, pp. 39-43, July 2016.

[5] Zeng Li, Zhang Zhongqiu, and Liu Yannan, "Innovation and entrepreneurship education in colleges and Universities need to cooperate with each other,” Educational Research, vol. 1, pp. 54-59, January 2017.

[6] Hao Jie, "American innovation and entrepreneurship education system construction and enlightenment," Higher Engineering Education Research,vol. 4, pp. 82-86, May 2016.

[7] Wang Zhanren, "Study on the disciplinary characteristics and development orientation of innovative entrepreneurship education in Chinese higher education,” Educational Research, vol. 3, pp. 29-35, June 2016. 